\title{
PERFORMANCE KETERAMPILAN DASAR MENGAJAR GURU PENDIDIKAN PANCASILA DAN KEWARGANEGARAAN SMP NEGERI 4 PARIAMAN
}

\author{
Marissa Dwi Putri, Al Rafni \\ Pendidikan Pancasila dan Kewarganegaraan \\ FIS Universitas Negeri Padang \\ Email : Marissadwiputri22@gmail.com
}

\begin{abstract}
This research is motivated by how the basic skills teachers civic education. the main problem of this research is related to performance the basic skills of teaching pancasila civic education teachers. This study aims to determine the basic teaching skills of pancasila civic education teachers in junior high school 4 Pariaman. The type of research used is descriptive field research with a quantitative approach. The population of this study were all IX graders totaling 196 people. While the sample in this study was 25,51\% of the total population. The sampling technique in this study is Probability Sampling with a simple random sampling pattern. The technique of collecting data through questionnaires and documentation. Processing data by testing requirements which include: testing data validity, testing data normality and testing data reliability. Next is descriptive analysis. The results showed that the basic teaching skills of pancasila civic education teachers in junior high school 4 Pariaman were in the good category with a percentage of $84.9 \%$.
\end{abstract}

Keywords : Teaching Basic Skill, Pancasila Civic Education Teachers

\begin{abstract}
Abstrak
Penelitian ini di latar belakangi oleh bagaimana keterampilan dasar mengajar guru PPKn. permasalahan pokok penelitian ini adalah berkaitan dengan keterampilan dasar mengajar guru PPKn. Penelitian ini bertujuan untuk mengetahui performance keterampilan dasar mengajar guru PPKn SMP Negeri 4 Pariaman. Jenis penelitian yang digunakan adalah field research dengan metode deskriptif melalui pendekatan kuantitatif. Populasi penelitian ini adalah seluruh siswa kelas IX yang berjumlah 196 orang. Sedangkan sampel dalam penelitian ini adalah 25, 51 \% dari total populasi. Teknik pengambilan sampel dalam penelitian ini Probability Sampling dengan pola simple random sampling. Teknik pengumpulan data melalui angket dan dokumentasi. Pengolahan data dengan cara uji persyaratan yang meliputi : uji validitas data, uji normalitas data dan uji reliabilitas data. Selanjutnya dilakukan analisis deskriptif. Hasil penelitian mengungkapkan bahwa keterampilan dasar mengajar guru PPKn SMP Negeri 4 Pariaman berada pada kategori baik dengan persentase 84,9\%.
\end{abstract}

Kata kunci : Keterampilan Dasar Mengajar, Guru PPKn. 


\section{7 |Performance Keterampilan...}

\section{PENDAHULUAN}

Mengajar merupakan sebagian dari kegiatan guru. Dimana mengajar dapat diartikan sebagai usaha untuk menciptakan kondisi atau sistem lingkungan yang mendukung untuk berlangsungnya proses belajar. Dalam proses belajar mengajar, seorang guru mempunyai peranan sangat penting untuk meningkatkan kemampuan siswanya atau guru merupakan fasilitator bagi anak didiknya. Berhasil atau tidaknya seorang guru dapat dilihat dari kemampuan siswanya setelah pelajaran diberikan.

Hal serupa juga diutarakan oleh beberapa penelitian terdahulu dari ( Jalal dan supriadi,2001) menyatakan bahwa tingkat penguasaan keterampilan mengajar guru dalam menggunakan metode yang inovatif masih kurang. Kondisi ini masih perlunya guru memperoleh bantuan atau bimbingan dari kepala sekolah.

(Underwood,1987) mengatakan bahwa keterampilan mengajar guru yang baik akan sangat mempengaruhi siswa dalam memandang kita dan pada gilirannya akan mempengaruhi perilaku mereka dalam belajar. Mengajar merupakan sebagian dari kegiatan guru. Dimana mengajar dapat diartikan sebagai usaha untuk menciptakan kondisi atau sistem lingkungan yang mendukung untuk berlangsungnya proses belajar. Dalam proses belajar mengajar, seorang guru mempunyai peranan sangat penting untuk meningkatkan kemampuan siswanya atau guru merupakan fasilitator bagi anak didiknya. Berhasil atau tidaknya seorang guru dapat dilihat dari kemampuan siswanya setelah pelajaran diberikan.

(Abu Ahmadi, 1998 : 44) menyatakan Keterampilan guru sangat dibutuhkan untuk meningkatkan keaktifan belajar siswa. (Syaiful Bahri Djamarah, 2000 : 99). Keterampilan mengajar guru perlu dilakukan secara bervariasi yang mana suatu kegiatan guru dalam kontek proses interaksi belajar mengajar yang ditujukan untuk mengatasi kebosanan murid. Sehingga dalam situasi belajar mengajar, murid senantiasa menunjukkan ketekunan, antusiasme serta penuh partisipasi, menghilangkan kebosanan, meningkatkan minat dan keingintahuan siswa, melayani gaya belajar siswa yang beragam, serta meningkatkan keaktifan siswa. (Nasution 2008 :155) menyatakan bahwa keterampilan mengajar seorang guru harus mempunyai berbagai gaya dan bisa menjalnkan perannya untuk menguasai pembelajaran yang efektif dan inovatif.

Adapun perbedaaan antara dengan penelitian terdahulu yakninya didalam penelitian penulis hanya mengemukakan keterampilan mengajar dalam proses pembelajaaran. sedangkan penelitian terdahulu lebih mengemukakan Keterampilan yang mana guru sangat dibutuhkan untuk meningkatkan keaktifan belajar siswa.

Keterbatasan solusi yang pernah ada yaitu tidak kebayankan peneliti mengemukakan pendapatan tentang keterampilan. Dimana Keterampilan mengajar perlu dilakukan secara bervariasi. Mengadakan Keterampilan 
mengajar secara bervariasi adalah suatu kegiatan guru dalam kontek proses interaksi belajar mengajar yang ditujukan untuk mengatasi kebosanan murid. Sehingga dalam situasi belajar mengajar, murid senantiasa menunjukkan ketekunan, antusiasme serta penuh partisipasi, menghilangkan kebosanan, meningkatkan minat dan keingintahuan siswa, melayani gaya belajar siswa yang beragam, serta meningkatkan keaktifan siswa.

Kelebihan solusi yang dalam penelitian ini yaitu untuk medeskripsikan keterampilan mengajar yang bevariasi. Yakninya Keterampilan dasar mengajar adalah suatu perbuataan yang komplek dalam arti penggunaan seacara integrasi dalam sejumlah komponen yang terdapat dalam perbuatan mengajar untuk menyampaikan suatu pesan pengajar.

Adapun tujuan penulisan artikel ini untu mendeskripsikan Performance Keterampilan Dasar Mengajar Guru Ppkn SMP N 4 Pariaman dalam mengatasi kejenuhan siswa dalam proses belajar.

\section{METODE PENELITIAN}

Penelitian ini dilakukan di lapangan, sehingga jenis penelitian disebut dengan field research, yaitu peneltian yang dilakukan dalam kehidupan yang sebenarnya. Penelitian ini juga disebut dengan penelitian deskriptif, karena penelitian ini berfokus pada menggambarkan fenomena lapangan yang detemui melalui hasil penelitian. Berdasarkan tujuan penelitian, permasalahan yang akan dikaji oleh peneliti merupakan masalah yang bersifat sosial dan dinamis (Sugiyono, 2014 : 60).

Menurut Trianto (2011 : 197), penelitian deskriptif adalah penelitian yang berusaha mendeskripsikan suatu gejala, peristiwa, kejadian yang terjadi saat sekarang. Penelitian ini bertujuan untuk mengetahui hal-hal yang berhubungan dengan keadaan atau gejala mengenai pendidikan tanpa menggunakan hipotesis karena, sifatnya hanya menggambarkan dan variabel yang diteliti hanya satu variabel. Di samping itu, penelitian ini menggunakan pendekatan kuantitatif dengan pengumpulan data melalui penyebaran angket/kuesioner kepada sampel penelitian. Data yang diperoleh melalui angket tersebut diolah dan dianalisis dengan statistik kualitiatif deskriptif yang disajikan dalam bentuk pengkategorian dan persentase.

Prosedur dalam penelitian ini terdiri dari 3 tahap, yaitu: 1) tahap persiapan, 2) tahap pelaksanaan, 3) tahap akhir.

\section{Tahap persiapan}

Langkah-langkah yang dilakukan pada tahap persiapan, antara lain:

(1) Merancang kisi-kisi tentang variabel keterampilan dasar mengajar guru 


\section{Performance Keterampilan...}

PPKn; (2) Menuangkan kisi-kisi instrument ke dalam angkket penelitian; (3) Melakukan validasi angket penelitian; (4) Merevisi instrument penelitian yaitu angket penelitian berdasarkan hasil validasi.

\section{Tahap pelaksanaan}

(1) Observasi pelaksanaan pembelajaran oleh guru dikelas dilakukan oleh peneliti; (2) Mengikuti kegiatan proses pembelajaran di kelas sebagai observer; (3) Mengisi lembar pengamatan sesuai dengan kegiatan yang ditampakkan selama pembelajaran PPKn berlangsung; (4) menyebarkan angket penelitian kepada sampel yaitu siswa kelas IX SMP Negeri 4 Pariaman.

\section{Tahap akhir}

(1) Mengolah data hasil penelitian dari hasil angket; (2) Menganalisis data;

(3) Mendeskripsikan hasil analisis data ke dalam pembahasan; (4) Membuat kesimpulan dari riset yang dilakukan; (5) Menyusun laporan penelitian.

\section{HASIL DAN PEMBAHASAN \\ Hasil Penelitian}

Penelitian ini dilakukan di SMP Negeri 4 Kota Pariaman dengan jumlah populasi penelitian sebanyak 196 orang siswa yang merupakan jumlah siswa kelas IX SMP Negeri 4 Pariaman. Sasmpel penelitian sebanyak 50 orang siswa dari total populasi.

\section{Analisis Deskriptif Keterampilan Dasar Mengajar Guru PPKn}

Pada analisis deskriptif ini, data yang sudah diperoleh akan dioleh sesuai dengan kebuuthan penelitian, yaitu untuk menjawab rumusan masalah penelitian, yaitu bagaimana keterampilan dasar mengajar guru PPKn SMP Negeri 4 Pariaman? Tahapan analisis yang penulis lakukan sesuai dengan tahapan yang telah penulis paparkan sebelumnya. Berikut ini data akan dianalisis secara berurutan berdasarkan hasil angkat yang telah penulis sebarkan kepada responden penelitian tentang keterampilan dasar mengajar guru PKn SMP Negeri 4 Pariaman.

\section{Keterampilan Bertanya Dasar}

Berdasarkan data distribusi frekuensi dari 50 orang responden dengan 13 item pernyataan dapat dapat dilihat bahwa untuk indikator keterampilan bertanya pada sub indikator keterampilan bertanya dasar diperoleh tingkat capaian sebesar 85,2\%. Dengan demikian dapat disimpulkan bahwa keterampilan dasar mengajar guru PPKn SMP Negeri 4 Pariaman berdasarkan keterampilan bertanya dasar berada pada kategori baik. Dengan rincian persentase jawaban responden : Selalu (A) $=41,69 \%$, Sering $(B)=45,23 \%$, Jarang $(C)=10,61 \%$, Jarang Sekali $(D)=$ $2,30 \%$ dan Tidak Pernah $(\mathrm{E})=0,15 \%$. 


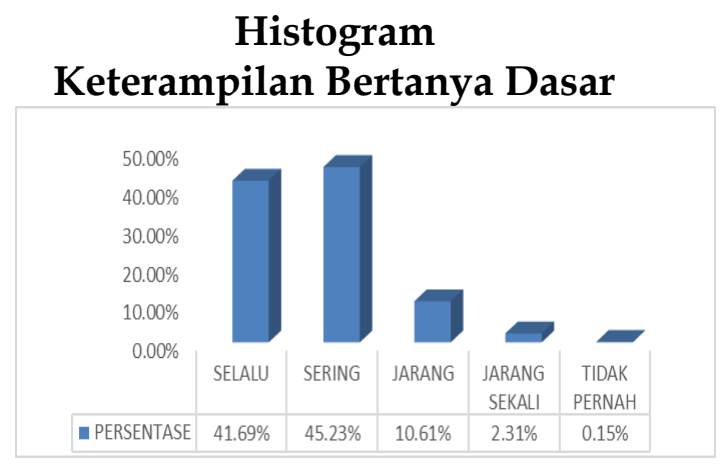

Hal ini ditunjukan oleh histogram keterampilan dasar mengajar guru PPKn SMP Negeri 4 Pariaman pada indikator keterampilan bertanya berdasarkan sub indikator keterampilan bertanya dasar berada pada tingkat capaian $85,2 \%$ yang berarti berada pada kategori baik.

\section{Keterampilan Bertanya Lanjut}

Berdasarkan data distribusi frekuensi dari 50 orang responden dengan 5 item pernyataan dapat dapat dilihat bahwa untuk indikator keterampilan bertanya pada sub indikator keterampilan bertanya lanjut diperoleh tingkat capaian sebesar 83,64\%. Dengan demikian dapat disimpulkan bahwa keterampilan dasar mengajar guru PPKn SMP Negeri 4 Pariaman berdasarkan keterampilan bertanya lanjut berada pada kategori baik. Dengan rincian persentase jawaban responden : Selalu $(A)=35,6 \%$, Sering $(B)=49,2 \%$, Jarang $(C)=13,6 \%$, Jarang Sekali $(D)=1,2 \%$ dan Tidak Pernah (E) $=0,4 \%$.

\section{Histogram}

Keterampilan Bertanya Lanjut

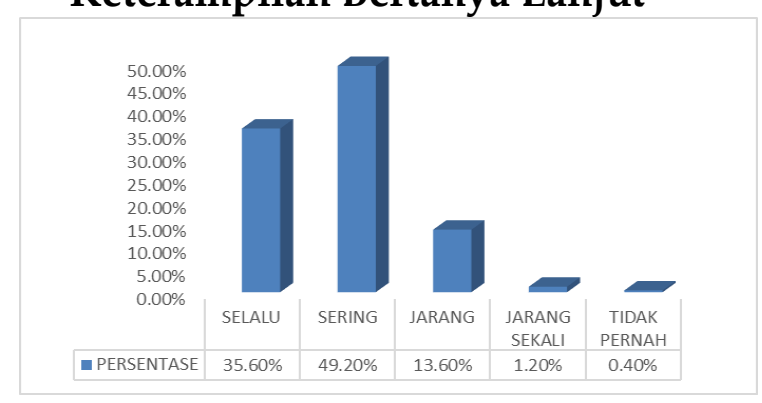

Hal ini ditunjukan oleh histogram keterampilan dasar mengajar guru PPKn SMP Negeri 4 Pariaman pada indikator keterampilan bertanya berdasarkan sub indikator keterampilan bertanya dasar berada pada tingkat capaian $83,64 \%$ yang berarti berada pada kategori baik.

\section{Keterampilan Melakukan Pendekatan}




\section{1 |Performance Keterampilan...}

Berdasarkan data distribusi frekuensi dari 50 orang responden dengan 2 item pernyataan dapat dapat dilihat bahwa untuk indikator keterampilan memberikan penguatan pada sub indikator keterampilan melakukan pendekatan diperoleh tingkat capaian sebesar 85,6\%. Dengan demikian dapat disimpulkan bahwa keterampilan dasar mengajar guru PPKn SMP Negeri 4 Pariaman berdasarkan keterampilan melakukan pendekatan berada pada kategori baik. Dengan rincian persentase jawaban responden : Selalu $(A)=42 \%$, Sering $(B)=47 \%$, Jarang $(C)=10 \%$, Jarang Sekali $(D)=0 \%$ dan Tidak Pernah $(\mathrm{E})=1 \%$.

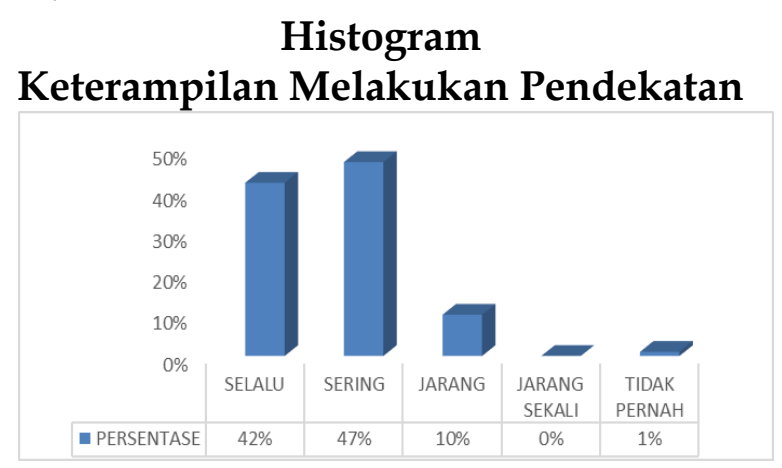

Hal ini ditunjukan oleh histogram keterampilan dasar mengajar guru PPKn SMP Negeri 4 Pariaman pada indikator keterampilan memberikan penguatan berdasarkan sub indikator keterampilan melakukan pendekatan berada pada tingkat capaian $85,6 \%$ yang berarti berada pada kategori baik.

\section{Keterampian Memberikan Penghargaan}

Berdasarkan data distribusi frekuensi dari 50 orang responden dengan 2 item pernyataan dapat dapat dilihat bahwa untuk indikator keterampilan memberikan penguatan pada sub indikator keterampilan memberikan penghargaan diperoleh tingkat capaian sebesar 80,8\%. Dengan demikian dapat disimpulkan bahwa keterampilan dasar mengajar guru PPKn SMP Negeri 4 Pariaman berdasarkan keterampilan memberikan penghargaan berada pada kategori baik. Dengan rincian persentase jawaban responden : Selalu $(A)=37 \%$, Sering $(B)=37 \%$, Jarang $(C)=26 \%$, Jarang Sekali $(D)=1 \%$ dan Tidak Pernah $(\mathrm{E})=1 \%$.

\section{Histogram}

\section{Keterampilan Memberikan Penghargaan}

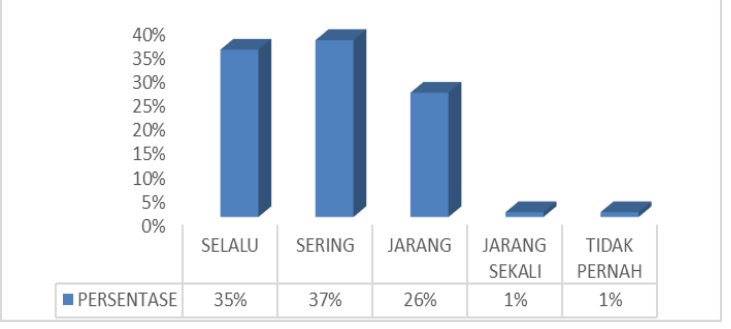


Hal ini ditunjukan oleh histogram keterampilan dasar mengajar guru PPKn SMP Negeri 4 Pariaman pada indikator keterampilan memberikan penguatan berdasarkan sub indikator keterampilan memberikan penghargaan berada pada tingkat capaian $80,8 \%$ yang berarti berada pada kategori baik.

\section{Keterampilan Memberikan Perhatian}

Berdasarkan data distribusi frekuensi dari 50 orang responden dengan 4 item pernyataan dapat dapat dilihat bahwa untuk indikator keterampilan memberikan penguatan pada sub indikator keterampilan memberikan perhatian diperoleh tingkat capaian sebesar 87,6\%. Dengan demikian dapat disimpulkan bahwa keterampilan dasar mengajar guru PPKn SMP Negeri 4 Pariaman berdasarkan keterampilan memberikan perhatian berada pada kategori sangat baik. Dengan rincian persentase jawaban responden : Selalu $(A)=49 \%$, Sering $(B)=41 \%$, Jarang $(C)=9 \%$, Jarang Sekali $(D)=1 \%$ dan Tidak Pernah $(\mathrm{E})=0 \%$.

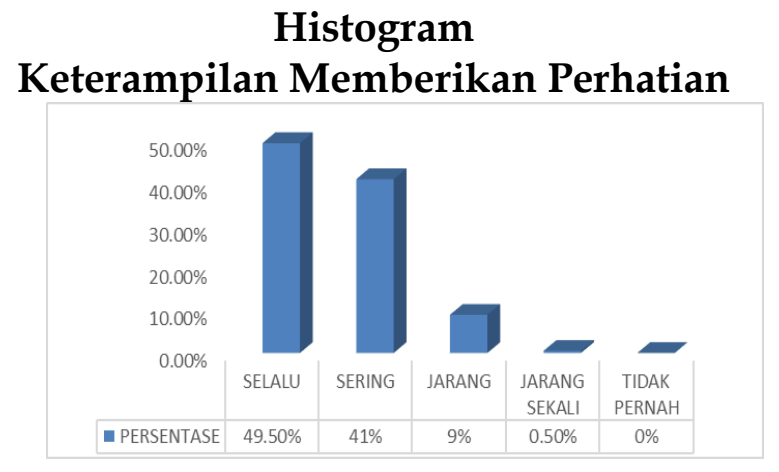

Hal ini ditunjukan oleh histogram keterampilan dasar mengajar guru PPKn SMP Negeri 4 Pariaman pada indikator keterampilan memberikan penguatan berdasarkan sub indikator keterampilan memberikan perhatian berada pada tingkat capaian $87,6 \%$ yang berarti berada pada kategori sangat baik.

6. Deskripsi Variabel Keterampilan Mengajar Guru PPKn SMP Negeri 4 Pariaman

Tabel

Variabel ketreampilan dasar mengajar guru PPKn SMP Negeri 4 Pariaman

\begin{tabular}{|l|l|l|l|l|l|}
\hline Valid & Skor & Skor & Skor & Frekuensi & Persentase \\
\hline
\end{tabular}


83 Performance Keterampilan...

\begin{tabular}{|l|l|l|l|l|l|}
\hline & $\begin{array}{l}\text { Perolehan } \\
\text { Maksimum }\end{array}$ & $\begin{array}{l}\text { Perolehan } \\
\text { Minimum }\end{array}$ & Ideal & $\begin{array}{l}\text { Skor } \\
\text { Rata-Rata }\end{array}$ & Capaian \\
\hline 50 & 128 & 80 & 130 & $110,48 \%$ & $84,98 \%$ \\
\hline
\end{tabular}

Hal ini ditnjukan oleh data yang dimuat di dalam tabel merupakan data keseluruhan skor perolehan tentang keterampilan dasar mengajar guru PPKn SMP Negeri 4 Pariaman. Berdasarkan tabel di atas dapat dijelaskan bahwa $\mathrm{N}$ jumlah data yang valid adalah 50. Sedangkan data yang hilang adalah nol, dapat diartikan bahwa semua data dapat diproses. Skor maksimum adalah 128 dan skor minimum 80. Skor ideal yang harus dicapai adalah 130, sedangkan frekuensi skor rata-rata tentang keterampilan dasar mengajar guru adalah 110,48.

Untuk mengetahui berapa tingginya persebaran data keterampilan dasar mengajar adalah hasil rata-rata dibagi dengan skor maksimum ideal, yaitu 110,48 : $130 \times 100 \%=84,98 \%$ (termasuk kategori baik). Hasil ini menunjukkan bahwa keterampilan dasar mengajar guru PPKn SMP 4 Pariaman termasuk kategori baik.

\section{Pembahasan}

Keterampilan Dasar Mengajar Guru PPKn SMP Negeri 4 Pariaman terdapat terdapat dua indikator yang telah diukur pada penelitian ini, masing-masing indikator memiliki sub indikator yang telah dituangkan ke dalam instrumen penelitian, yaitu : pertama; keterampilan bertanya dasar dan keterampilan bertanya lanjut yang merupakan sub dari indikator keterampilan bertanya. Kedua ; keterampilan melakukan pendekatan, keterampilan memberikan penghargaan dan keterampilan memberikan perhatian yang merupakan sub dari indikator keterampilan memberi penguatan. Oleh sebab itu, perlu adanya pembahasan dari masing-masing sub indikator terebut, yang akan dibahas sebagai berikut.

\section{Keterampilan Bertanya Dasar}

Tingkat keterampilan dasar mengajar guru PPKn SMP Negeri 4 Pariaman berdasarkan faktor keterampilan bertanya dasar. Persentase yang diperoleh pada faktor keterampilan bertanya dasar ini sebesar 85,2 \%. Berdasarkan persentase ini, dapat disimpilkan bahwa tingkat capain keterampilan dasar mengajar guru PPKn SMP Negeri 4 Pariaman dari keterampilan bertanya dasar berada pada kategori baik.

Oleh sebab itu, seorang guru harus terus belajar dan terus meningkatkan kualitasnya sebagai seorang guru dalam mengimplementasikan kemampuan dasarnya tentang keterampilan bertanya dasar, sehingga dengan spesifik kemampuannya dalam bertanya dasar ini dapat mencapai tujuan bertanya sebagaimana penggunaan pertanyaan itu sendiri. 
Untuk dapat mencapai tujuan penggunaan pertanyaan di dalam kelas, guru perlu mempunyai komponen-komponen keterampilan bertanya dasar_terdiri atas beberapa komponen yang perlu diterapkan oleh guru dalam mengajukan berbagai jenis pertanyaan. sebagaimana disampaikan Moh. User Usman dalam buku Menjadi Guru Professional (2010:7-78), sebagai berikut :Mengajukan pertanyaan secara jelas dan singkat,Memberi acuan,Pemusatan pertanyaan,Pemindahan giliran,Penyebaran,Memberi waktu berfikir dan Memberikan tuntunan. Dalam proses pembelajaran, tujuan utama pertanyaan yang diajukan guru adalah agar siswa belajar dengan harapan memperoleh pengetahuan dan meningkatkan kemampuan berpikirnya, oleh karena itu komponen-komponen keterampilan bertanya dasar di atas seharusnya merupakan keterampilan bertanya yang wajib dikuasai/dimiliki oleh seorang guru.

\section{Keterampilan Bertanya Lanjut}

Tingkat capaian keterampilan dasar mengajar guru PPKn SMP Negeri 4 Pariaman dilihat dari sub indikator keterampilan bertanya lanjut dengan persentase sebesar 83,68 \%. Tingkat capaian ini memberikan kesimpulan bahwa keberhasilan guru dalam keterampilan dasar mengajar dengan sub indicator keterampilan bertanya lanjut pada kategori baik.

Keterampilan bertanya lanjutnya dengan kategori baik. Akan tetapi belum mencapai tingkat maksimal. Oleh sebab itu, guru harus lebih meningkatkan pengetahuan dan kemampuan dalam menerapkan keterampilannya tentang bertanya lanjut. (Samion dkk, 2009) menyatakan bahwa guru hendaknya dapat mengatur pertanyaan-pertanyaan yang akan di ajukan kepada siswa. Guru diharapkan dapat merubah tuntutan pertanyaan ke tingkat kognitif siswa dalam menjawab pertanyaan dan meningkatkan tingkat interaksi di dalam kelas, baik antar siswa dengan siswa, maupun antar siswa dengan guru. Dengan demikian, tujuan dari keterampilan bertanya secara umum akan tercapai dengan baik.

\section{Keterampilan Melakukan Pendekatan}

Keterampilan dasar mengajar guru PPKn SMP Negeri 4 Pariaman pada sub indikator keterampilan melakukan pendekatan. Persentase capaiannya sebesar 85,6\%. Dari persentase ini dapat disimpulkan bahwa keterampilan dasar mengajar guru PPKn SMP Negeri 4 Pariaman dengan sub indikator keterampilan melakuakn pendekatan berada pada kategori baik.

Jadi, hasil penelitian ini menunjukkan bahwa keterampilan dasar mengajar guru PPKn SMP Negeri 4 Pariaman pada keterampilan melakukan pendekatan telah berhasil dengan baik, namun perlu ditingkatkan. Hal ini dikeranakan melakukan pendekatan terhadap siswa, baik secara individu, 


\section{5 |Performance Keterampilan...}

maupun terhadap kelompok merupakan hal yang sangat penting. Sebab, latar belakang setiap siswa berbeda, sehingga perbedaan tersebut akan membawa dampak yang berbeda pula kepada tingkat keberhasilan siswa. (mulyasa 2007:99) menyatakan keterampilan melakukan pendekatan nerupkan suatu proses dalam belajar agar peserta didik memperoleh nilai dan sikap dalam kehidupan sehari-harinya. Guru memegang peranan penting dalam menanggulangi setiap pemasalahan siswa. Mulai dari permasalahan kesulitan belajar, sampai kepada permasalahan tingkah laku. Dengan melakukan pendekatan yang baik dan tepat, diharapkan guru mampu mengatasi permasalahan-permasalahan tersebut, sehingga siswa bisa lebih giat berpastisipasi dalam interaksi pembelajaran.

\section{Keterampilan Memberikan Penghargaan}

Tingkat keberhasilan guru dalam keterampilan dasar mengajar dengaan sub indikator keterampilan memberikan penghargaan. Persentase keterampilan dasar mengajar guru PPKn SMP Negeri 4 Pariaman pada sub indiketor keterampilan memberikan penghargaan sebesar 80,8\%. Persentase ini menjelaskan bahwa keterampilan dasar mengajar guru PPKn SMP Negeri 4 Pariaman berada pada kategori baik. keterampilannya dalam hal memberi penghargaan dengan baik. Akan tetapi belum mencapai tingkat maksimal sebagaimana yang diharapkan. Guru harus lebih meningkatkan keterampilan memberikan pernghargaan.

Syaiful Sagala menyebutkan, penghargaan disebut juga dengan Reward yang berarti salah satu keterampilan dalam mengajar (2010: 14). Beberapa langkah yang bisa dilakukan oleh guru dalam memberikan pengharagaan kepada siswa, yang mana sebagai tanda senang atau membenarkan jawaban siswa dengan Kata-kata yang menggembirakan (pujian) sehingga pekerjaan dengan tingkat yang lebih sukar seperti Ganjaran yang ditujukan kepada seluruh kelas, misalnya bernyanyi atau berwisata bersama.

Dari ungkapan di atas, dapat penulis tegaskan agar guru mampu memberikan penghargaan kepada siswa agar dapat merangsang motivasi belajar siswa. Pernghargaan bukan hanya dalam bentuk materi dan konpensasi saja. Lebih umum, penghargaan upaya untuk memberikan rangsangan terhadap semangat yang ada di dalam diri siswa. Sebuah pujian, juga bisa berfungsi sebagai penghargaan. Dengan demikian, guru hendaknya mampu memberikan jenis penghargaan yang bervariasi sesuai dengan situasi siswa.

\section{Keterampilan Memberikan Perhatian}

Keterampilan dasar mengajar guru PPKn SMP Negeri 4 Pairman dengan sub indikator keterampilan memberikan perhatian, berhasil pada tingkat sangat baik dengan tingkat capaian persentase 87,6\%. Dari perolehan data di atas, terlihat bahwa keberhasilan guru dalam keterampilan dasar mengajar dengan sub indikator keterampilan memberikan perhatian sangat baik. Akan tetapi, persentase $87.6 \%$ belum juga mencapai tingkat maksimal. Zainal Asril menyebutkan keterampilan guru dalam memberikan perhatian 
dapat dilaksanakan dengan pola sebagai berikut $(2010,110)$ : Menunjukkan sikap tanggap,Memandang dengan seksama, Memberikan pernyataan, Gerak mendekati, Memberikan reaksi terhadap gangguan siswa,Memberikan petunjuk dan Menegur

Untuk mencapai keberhasilan yang lebi baik dalam memberikan perhatian kepada siswa, guru didorong untuk terus meningkatkan keterampilannya. Hal ini disebabkan karena salah satu peran guru di sekolah adalah sebagai orang tua bagi siswa. Eksistensi guru sebagai orang tua bagi siswa menjadikannya sebagai orang pertama yang akan memberikan perhatian terhadap siswa. Perhatian yang dimaksud adalah perhatian yang berorientasi pada keberhasilan siswa dalam prestasi belajar, tekun dan sabar dalam menjalani proses pembelajaran dan mampu membawa perubahan terhadap tingkah lakunya.

\section{KESIMPULAN dan SARAN \\ Kesimpulan}

Keterampilan guru sangat dibutuhkan untuk meningkatkan keaktifan belajar siswa. Keterampilan mengajar perlu dilakukan secara bervariasi. Mengadakan Keterampilan mengajar secara bervariasi adalah suatu kegiatan guru dalam kontek proses interaksi belajar mengajar yang ditujukan untuk mengatasi kebosanan murid. Sehingga dalam situasi belajar mengajar, murid senantiasa menunjukkan ketekunan, antusiasme serta penuh partisipasi, menghilangkan kebosanan, meningkatkan minat dan keingintahuan siswa, melayani gaya belajar siswa yang beragam, serta meningkatkan keaktifan siswa (Syaiful Bahri Djamarah, 2000 : 99).

Dari hasil penelitian tentang keterampilan dasar mengajar guru PPKn SMP Negeri 4 Pariaman, pada aspek keterampilan bertanya dasar dengan jumlah responden 50 orang siswa dan item pernyataan sebanyak 26 item, 13 item diperoleh dengan persentase 85,2 \% berada pada kategori baik. Pada aspek Keterampilan bertanya lanjut 5 item, diperoleh dengan persentase 83,68 \% berada pada kategori baik.. Pada aspek keterampilan melakukan pendekatan dengan item pernyataan sebanyak 2 item, diperoleh dengan persentase 85,5 \% berada pada kategori baik. Pada aspek keterampilan memberikan penghargaan item pernyataan sebanyak 2 item, diperoleh dengan persentase $80,8 \%$ berada pada kategori baik. Dengan rincian persentase jawaban responden. Pada aspek keterampilan memberikan perhatian item pernyataan sebanyak 4 item, diperoleh dengan persentase $87,6 \%$ berada pada kategori sangat baik. 


\section{7 |Performance Keterampilan...}

Data peneitian dan hasil penelitian tentang variabel keterampilan dasar mengajar guru PPKn SMP Negeri 4 Pariaman, pada aspek keterampilan memberikan perhatian dengan jumlah responden 50 orang siswa dan item pernyataan sebanyak 26 item, diperoleh dengan persentase $84,98 \%$ berada pada kategori sangat baik. Dengan rincian kumulatif jawaban responden : Skor maksimum adalah 128 dan skor minimum 80. Skor ideal yang harus dicapai adalah 130, sedangkan frekuensi skor rata-rata tentang keterampilan dasar mengajar guru adalah 110,48.

\section{Saran}

Berdasarkan hasil penelitian yang ditemukan tentang keterampilan dasar mengajar guru PPKn SMP Negeri 4 Pariaman, maka penulis memberikan memberikan :

1. Kepada Kepala Sekolah SMP Negeri 4 Pariaman diharapkan dapat mensupervisi kinerga guru PPKn SMP Negeri 4 Pariaman berkaitan dengan keterampilan dasar mengajar agar bisa dievaluasi supaya terjadi peningkatan ke tingkat capaian yang lebih maksimal.

2. Kepada guru PPKn SMP Negeri 4 Pariaman agar dapat meningkatkan tingkat capaian keterampilan dasar mengajar supaya tujuan pembelajaran dapat tercapai dengan baik.

\section{RUJUKAN}

Djamarah, Syaiful Bahri, Guru dan Anak Didik dalam Interaksi Edukatif, Jakarta: PT. Rineka Cipta, 2000

Asril, Zainal, Pembelajaran Micro, Jakarta : Al-Bayan, 2007

, Micro Teaching, Jakarta : PT. Raja Grafindo Persada, 2010

Darajat, Zakiah, Pengajaran Agama Islam, Jakarta :Bumi Aksara, 2004

Ramayulis, Profesi dan Etika Keguruan, Jakarta : Kalam Mulia, 2013

Sugiyono, Metode Penelitian Kombinasi, Bandung: Alfabeta, 2012

Metode Penelitian Pendidikan: Pendekatan Kuantitatif, Kualitatifdan RED, Bandung: Alfabeta, 2014

Statistika Untuk Penelitian, Bandung : Alfabeta, 2015

Syaodah, Nana, Sukmadinata, Landasan Psikologi Proses Pendidikan, Bandung : PT Remaja Rosdakarya, 2000

Uzer, Moh,Usman, Menjadi Guru Profesional, Bandung: PT Remaja Rosdakarya, 2002

Nasution, S., Didaktik Asas-Asas Mengajar, Jakarta: PT. Bumi Aksara, 1982

Nasution, S., Didaktik Asas-Asas Mengajar, Jakarta: PT.Bumi Aksara, 1982 